\title{
Correlation between pathological and clinical findings in 195 consecutive liver biopsies showing brown pigment
}

\author{
NIELS TYGSTRUP, TORBEN SCHIØDT, AND KJELD WINKLER \\ From the Medical Department B, Rigshospitalet, and the Institute of \\ Pathological Anatomy, University of Copenhagen, Copenhagen, Denmark
}

EDITORIAL SYNOPSIS 'Brown lipofuscin' pigment is not uncommon in liver biopsy specimens from the hospital population. This particular study describes such pigment in $15 \%$ of 195 needle biopsy samples. The association with unexplained hepatomegaly and with an asthenic 'presenile' look has not hitherto been described.

The accumulation of brown pigment granules in the parenchymal liver cells is a well known phenomenon, especially in atrophic, dark organs from old people or from patients with debilitating diseases (brown atrophy of the liver). It has been attributed to decreased metabolic activity and therefore been called 'wear and tear' pigment (Hanser, 1930). Its origin and metabolism remains obscure but presumably it is contained in the lysosomes (Essner and Novikoff, 1960). The staining properties indicate that it partly consists of lipids (Pearse, 1960), hence the term lipofuscin, but otherwise its chemical constitution is not known.

During the last decade new interest in this pigment has been aroused, particularly by the demonstration of a connexion between hepatic pigmentation and constitutional hyperbilirubinaemia (Dubin and Johnson, 1954; Sprinz and Nelson, 1954). About the same time it became clear from other studies (Post, Benton, and Breakstone, 1951; Bachmann 1953) that the pigment may concentrate in considerable amounts in the liver of younger people and on the whole it is frequently found.

It has been claimed that the pigment found in cases with chronic idiopathic jaundice (Dubin and Johnson, 1954) is different from ordinary lipofuscin (Dubin, 1958; Ehrlich, Novikoff, Platt, and Essner, 1960), but with the usual histological techniques only minor quantitative differences are demonstrable (Hamperl, 1957). Furthermore the association between this type of jaundice (with mainly conjugated bilirubin in the serum) and hepatic pigmentation seems to be inconstant, since cases with jaundice but no pigment (Porush, Delman, and Feuer, 1962) and others with pigmentation but without jaundice (Burka, Brick, and Wolfe, 1961) have been described, and pigment also has been demonstrated in chronic jaundice with mainly unconjugated bilirubin in the serum (Sagild, Dalgaard, and Tygstrup, 1962).

This leaves the question of the pathological significance of the pigmentation unsettled, and consequently the presence of lipofuscin is usually disregarded. In the present work an attempt was made to evaluate the importance of hepatic lipofuscin in needle biopsy material, partly by determining the frequency with which lipofuscin granules were found in the material, partly by seeking common clinical features among patients in whom the hepatic pigmentation was marked.

\section{MATERIALS AND METHODS}

The material comprises 195 consecutive biopsies of the liver obtained during 10 years in one medical department. The number of biopsies steadily increased, being three during the first year and 68 during the last year. Sixteen samples represented repeated biopsies, and the material thus comprises biopsies from 179 patients ( 86 women and $93 \mathrm{men})$. In the frequency studies only the first biopsy from each patient has been considered.

The pigmentation of the biopsy specimens was assessed by one of us (T.S.) by examining the existing slides, prepared by a uniform technique during the period (fixation in 10\% formalin, paraffin sections, and staining with haematoxylin and eosin). In most cases the appearance of the pigment was absolutely characteristic (Fig. 1). It consists of angular, irregular granules, 1 to $1.5 \mu$ in 
diameter, usually of a dark brown colour, but varying from light orange to almost black. The granules are localized in the cytoplasm of the parenchymal cells near the cell surface facing the bile canaliculus. Pigment in the Kupffer cells has not been considered here. Lipofuscin was distinguished from bile pigment on a morphological basis, the latter being more amorphous and of a more greenish colour. In a few cases with very little pigment this distinction was difficult, and they were recorded as lipofuscin-negative. When haemosiderin pigmentation was considered a possibility, a fresh section was stained for iron, and, if positive, all the pigment of the specimen was regarded as haemosiderin.

The degree of pigmentation was graded as follows: grade $\mathbf{O}=$ no granules; grade $(+)=$ a few granules after careful examination; grade $+=$ easily found granules, but only a few in each cell, and only in a minority of the cells; grade $++=$ almost all the cells in the affected areas contained considerable amounts of granules; grade $+++=$ all the cells in the affected areas were heavily pigmented.

The classification was performed without knowledge of the clinical data of the patients, and the reproducibility was examined by re-classification of 41 specimens, without knowledge of the first result. In 29 cases $(70 \%)$ the two classifications were identical, in the remaining 12 cases, which all but one belonged to the three lowest grades, it differed by one grade. The mean difference between the first and the second classification was $-\mathbf{0 . 2}$ grade (standard deviation 0.5 ).

In 16 cases two biopsies had been taken, the interval between them varying from six months to seven years. In eight cases the grade of pigmentation was the same in both, in four cases they differed by more than one grade. The mean change from the first to the second biopsy was $-0 \cdot 4$ grade (standard deviation $1 \cdot 1$ ). The mean is not significantly different from zero, but the variance is significantly greater than that of the reproducibility of the classification. This variation may either be due to fluctuations in the amount of pigment with time or to variations within the relatively small area where the biopsies were taken. Necropsy studies have shown that the pigmentation tends to be uniformly distributed in the liver (Post et al., 1951); it is therefore most likely that the pigmentation varies with time.

\section{RESULTS}

The laboratory results and clinical findings are summarized in Tables I and II.

Figure 2 shows the frequency of the different grades of pigmentation in younger and older patients, using the age of 50 as the line of separation. It appears that marked pigmentation of the liver cells, i.e., grade ++ and +++ , occurred in $18 \%$ of the

TABLE I

LABORATORY FINDINGS

\begin{tabular}{|c|c|c|c|c|c|c|c|c|c|c|c|c|c|}
\hline $\begin{array}{c}\text { Group Case } \\
\text { No. }\end{array}$ & $\begin{array}{l}\text { Age } \\
(y r .)\end{array}$ & Sex & $\begin{array}{l}\text { Body } \\
\text { Weight } \\
\text { (kg.) }\end{array}$ & $\begin{array}{l}\text { History } \\
\text { of } \\
\text { Jaundice }\end{array}$ & $\begin{array}{l}\text { History } \\
\text { of } \\
\text { Abdominal } \\
\text { Pain }\end{array}$ & $\begin{array}{l}\text { Hepato- } \\
\text { megaly }\end{array}$ & $\begin{array}{l}\text { B.S.R. } \\
(\mathrm{mm} . / \mathrm{hr} .)\end{array}$ & $\begin{array}{l}\text { Serum } \\
\text { Bilirubin } \\
\text { (mg./100 ml.) }\end{array}$ & $\begin{array}{l}\text { Thymol } \\
\text { Turbidity } \\
\text { (extinction } \\
\text { units) }\end{array}$ & $\begin{array}{l}\text { Alkaline } \\
\text { Phosphatase } \\
\text { (K.A.units) }\end{array}$ & $\begin{array}{l}\text { Bromsul- } \\
\text { phalein } \\
\text { Retention }\end{array}$ & $\begin{array}{l}\text { Visual- } \\
\text { ization } \\
\text { on Oral } \\
\text { Chole- } \\
\text { cysto- } \\
\text { graphy }\end{array}$ & 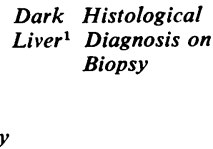 \\
\hline
\end{tabular}

\begin{tabular}{|c|c|c|c|c|c|c|c|c|c|c|c|c|c|c|c|}
\hline I & 1 & 58 & $\mathbf{M}$ & 56 & No & No & No & 110 & $2 \cdot 1$ & 0.05 & $25 \cdot 0$ & n.o. & n.o. & n.o. & Severe cirrhosis \\
\hline II & $\begin{array}{l}2 \\
3 \\
4 \\
5\end{array}$ & $\begin{array}{l}48 \\
49 \\
26 \\
39\end{array}$ & $\begin{array}{l}\mathbf{M} \\
\mathbf{M} \\
\mathbf{F} \\
\mathbf{M}\end{array}$ & $\begin{array}{l}71 \\
61 \\
51 \\
61\end{array}$ & $\begin{array}{l}\text { No } \\
\text { No } \\
\text { Yes } \\
\text { No }\end{array}$ & $\begin{array}{l}\text { No } \\
\text { No } \\
\text { No } \\
\text { No }\end{array}$ & $\begin{array}{l}\text { Yes } \\
\text { Yes } \\
\text { No } \\
\text { Yes }\end{array}$ & $\begin{array}{r}1 \\
55 \\
95 \\
12\end{array}$ & $\begin{array}{r}1 \cdot 1 \\
12 \cdot 0 \\
1 \cdot 8 \\
2 \cdot 5\end{array}$ & $\begin{array}{l}\text { n.o. } \\
0.13 \\
0.21 \\
0.01\end{array}$ & $\begin{array}{l}\text { n.o. } \\
31 \cdot 0 \\
28 \cdot 0 \\
15 \cdot 0\end{array}$ & $\begin{array}{r}\text { n.o. } \\
46 \cdot 0 \\
1 \cdot 4 \\
27 \cdot 6\end{array}$ & $\begin{array}{l}\text { n.o. } \\
+ \\
+\end{array}$ & $\begin{array}{l}+(n) \\
\text { n.o. } \\
\text { n.o. } \\
-(b)\end{array}$ & $\begin{array}{l}\text { Slight fibrosis } \\
\text { Cholestasis } \\
\text { Slight infiltration }{ }^{2} \\
\text { Slight infiltration }\end{array}$ \\
\hline III & $\begin{array}{l}6 \\
7 \\
8 \\
9\end{array}$ & $\begin{array}{l}63 \\
57 \\
65 \\
66\end{array}$ & $\begin{array}{l}\mathbf{F} \\
\mathbf{M} \\
\mathbf{F} \\
\mathbf{F}\end{array}$ & $\begin{array}{l}75 \\
61 \\
49 \\
73\end{array}$ & $\begin{array}{l}\text { No } \\
\text { No } \\
\text { No } \\
\text { No }\end{array}$ & $\begin{array}{l}\text { No } \\
\text { No } \\
\text { No } \\
\text { No }\end{array}$ & $\begin{array}{l}\text { No } \\
\text { Yes } \\
\text { Yes } \\
\text { No }\end{array}$ & $\begin{array}{r}65 \\
78 \\
1 \\
105\end{array}$ & $\begin{array}{l}0.6 \\
1.0 \\
0.5 \\
0.3\end{array}$ & $\begin{array}{l}0.03 \\
0 \cdot 18 \\
0.02 \\
0.07\end{array}$ & $\begin{array}{r}\text { n.o. } \\
21 \cdot 0 \\
9 \cdot 1 \\
4 \cdot 9\end{array}$ & $\begin{array}{r}\text { n.o. } \\
20 \cdot 5 \\
8 \cdot 2 \\
19 \cdot 0\end{array}$ & $\begin{array}{l}\text { n.o. } \\
+ \\
\text { n.o. } \\
(+)\end{array}$ & $\begin{array}{l}-(b) \\
-(p) \\
+(p) \\
\text { n.o. }\end{array}$ & $\begin{array}{l}\text { Normal } \\
\text { Slight infiltration } \\
\text { Normal } \\
\text { Pronounced } \\
\text { steatosis }\end{array}$ \\
\hline & $\begin{array}{l}10 \\
11 \\
12 \\
13 \\
14 \\
15 \\
16\end{array}$ & $\begin{array}{l}50 \\
50 \\
39 \\
38 \\
40 \\
36 \\
56\end{array}$ & $\begin{array}{l}\mathbf{M} \\
\mathbf{M} \\
\mathbf{M} \\
\mathbf{F} \\
\mathbf{F} \\
\mathbf{F} \\
\mathbf{F}\end{array}$ & $\begin{array}{l}57 \\
70 \\
54 \\
43 \\
49 \\
56 \\
58\end{array}$ & $\begin{array}{l}\text { No } \\
\text { No } \\
\text { No } \\
\text { No } \\
\text { No } \\
\text { No } \\
\text { No }\end{array}$ & $\begin{array}{l}\text { No } \\
\text { No } \\
\text { Yes } \\
\text { Yes } \\
\text { Yes } \\
\text { Yes } \\
\text { Yes }\end{array}$ & $\begin{array}{l}\text { No } \\
\text { Yes } \\
\text { Yes } \\
\text { No } \\
\text { Yes } \\
\text { No } \\
\text { No }\end{array}$ & $\begin{array}{r}12 \\
7 \\
3 \\
18 \\
7 \\
8 \\
86\end{array}$ & $\begin{array}{l}\text { n.o. } \\
0.4 \\
0.5 \\
0.5 \\
0.3 \\
0.6 \\
0.2\end{array}$ & $\begin{array}{l}\text { n.o. } \\
0.03 \\
0.03 \\
0.03 \\
0.11 \\
0.06 \\
0.04\end{array}$ & $\begin{array}{r}\text { n.o. } \\
7 \cdot 8 \\
\text { n.o. } \\
9.0 \\
13.0 \\
8.5 \\
11 \cdot 4\end{array}$ & $\begin{array}{r}\text { n.o. } \\
2 \cdot 0 \\
1 \cdot 5 \\
1 \cdot 1 \\
6 \cdot 0 \\
1 \cdot 7 \\
4 \cdot 0\end{array}$ & $\begin{array}{l}\text { n.o. } \\
+ \\
- \\
- \\
+ \\
+ \\
+\end{array}$ & $\begin{array}{l}\text { n.o. } \\
+(p) \\
+(1) \\
+(b) \\
+(p) \\
-(b) \\
\text { n.o. }\end{array}$ & $\begin{array}{l}\text { Normal } \\
\text { Normal } \\
\text { Normal } \\
\text { Normal } \\
\text { Normal } \\
\text { Normal } \\
\text { Normal }\end{array}$ \\
\hline IV & $\begin{array}{l}17 \\
18 \\
19 \\
20 \\
21 \\
22 \\
23 \\
24 \\
25 \\
26\end{array}$ & $\begin{array}{l}40 \\
33 \\
46 \\
31 \\
54 \\
56 \\
45 \\
38 \\
63 \\
41\end{array}$ & $\begin{array}{l}\mathbf{F} \\
\mathbf{M} \\
\mathbf{F} \\
\mathbf{M} \\
\mathbf{F} \\
\mathbf{F} \\
\mathbf{F} \\
\mathbf{F} \\
\mathbf{F} \\
\mathbf{F}\end{array}$ & $\begin{array}{l}76 \\
59 \\
58 \\
61 \\
52 \\
35 \\
38 \\
81 \\
51 \\
49\end{array}$ & $\begin{array}{l}\text { Yes } \\
\text { Yes } \\
\text { Yes } \\
\text { Yes } \\
\text { No } \\
\text { No } \\
\text { No } \\
\text { No } \\
\text { No } \\
\text { No }\end{array}$ & $\begin{array}{l}\text { Yes } \\
\text { No } \\
\text { No } \\
\text { Yes } \\
\text { No } \\
\text { Yes } \\
\text { Yes } \\
\text { No } \\
\text { Yes } \\
\text { Yes }\end{array}$ & $\begin{array}{l}\text { No } \\
\text { No } \\
\text { No } \\
\text { No } \\
\text { No } \\
\text { No } \\
\text { No } \\
\text { No } \\
\text { No } \\
\text { No }\end{array}$ & $\begin{array}{r}23 \\
4 \\
5 \\
2 \\
16 \\
5 \\
3 \\
9 \\
8 \\
5\end{array}$ & $\begin{array}{l}0.8 \\
1.4 \\
1.8 \\
1.7 \\
0.5 \\
0.4 \\
0.4 \\
0.7 \\
0.3 \\
0.6\end{array}$ & $\begin{array}{l}0.05 \\
0.07 \\
0.10 \\
0.10 \\
0.29 \\
0.04 \\
0.11 \\
0.11 \\
0.15 \\
0.04\end{array}$ & $\begin{array}{r}3.9 \\
7 \cdot 7 \\
5 \cdot 2 \\
3 \cdot 3 \\
\text { n.o. } \\
4 \cdot 5 \\
4 \cdot 5 \\
4 \cdot 7 \\
5 \cdot 2 \\
1 \cdot 8\end{array}$ & $\begin{array}{r}2.0 \\
8.0 \\
1.2 \\
\text { n.o. } \\
2.2 \\
0.0 \\
0.1 \\
1.9 \\
1.9 \\
3.5\end{array}$ & $\begin{array}{l}+ \\
+ \\
+ \\
+ \\
+ \\
+ \\
+ \\
+ \\
+ \\
+\end{array}$ & $\begin{array}{l}\text { n.o. } \\
\text { n.o. } \\
\text { n.o. } \\
-(\text { b) } \\
-(\text { p) } \\
+(\text { b) } \\
+(p) \\
-(b) \\
+ \text { (p) } \\
-(\text { b) }\end{array}$ & $\begin{array}{l}\text { Normal } \\
\text { Normal } \\
\text { Normal } \\
\text { Slight infiltration } \\
\text { Normal } \\
\text { Normal } \\
\text { Normal } \\
\text { Normal } \\
\text { Normal } \\
\text { Normal }\end{array}$ \\
\hline
\end{tabular}

n.o. = no observation

${ }^{\mathbf{n}} \mathbf{n}=$ necropsy; $1=$ laparotomy $; \mathrm{b}=$ biopsy; $\mathrm{p}=$ peritoneoscopy.

'Slight infiltration with mononuclear cells in the periportal spaces. 
I 1 Chronic alcoholism, ascites, and liver insufficiency.

II 2 Congestive heart failure. Necropsy: organized thrombi in the pulmonary artery.

3 Laparotomy: tumour infiltrates in the porta hepatis.

4 During the last trimester of pregnancy hypertension, albuminuria, and jaundice. After delivery (at the time of the liver biopsy) rapidly improving liver function.

III 5 Chlorpromazine jaundice. A test dose, given later, provoked another, short-lasting attack.

III 6 Periodic fever for many years. Slight albuminuria, positive L.E. cell phenomenon. Muscle biopsy: perivasicular infiltrations. Epilepsy treated with barbiturates and mysoliner.

7 For one year fatigue and dyspnoea. Serum gamma globulin $2.0 \mathrm{~g} . / 100 \mathrm{ml}$. Later on pulmonary infiltrates, congestive heart failure, and thrombosis of the right femoral artery (?periarteritis nodosa). Peritoneoscopy: hepatomegaly, capsular fibrosis.

8 For one year and a half fatigue and dyspnoea, loss of weight $(15 \mathrm{~kg}$.). Diffuse pulmonary infiltrates of unknown aetiology. Peritoneoscopy: hepatomegaly and capsular fibrosis.

9 For three months constant fever. A small pulmonary infiltrate of unknown aetiology. Chest $x$-ray three months later normal.

10 Slight dyspnoea for several years. Pulmonary infiltrates resembling sarcoidosis, lymph node biopsy normal.

11 Pulmonary infiltrates discovered incidentally one year previously. Later on tubercle bacilli were found by gastric lavage. Hepatomegaly demonstrated 10 years previously. Peritoneoscopy: hepatomegaly, capsular fibrosis.

12 Uncharacteristic dyspepsia and fatigue for 4 years. Anaemia (Hb $10 \cdot 2 \mathrm{~g} . / 100 \mathrm{ml}$.), apparently haemolytic, of unknown origin, Exploratory laparotomy: hepato-splenomegaly.

13 Abdominal pains for many years, several laparotomies (some exploratory). Haemolytic anaemia ( $\mathrm{Hb} \mathrm{9.5} \mathrm{g./100} \mathrm{ml.)} \mathrm{of} \mathrm{unknown}$ aetiology. Chronic pyelonephritis (serum creatinine $2.0 \mathrm{mg} . / 100 \mathrm{ml}$.). Abuse of analgesics.

14 Four years ago operation for peptic ulcer. Vaginal bleeding for 6 months, anaemia (Hb 8.6 g./100 ml.). Peritoneoscopy: hepatomegaly, capsular fibrosis.

15 Two years ago cholecystectomy. Several attacks of acute pyelonephritis (serum creatinine $1.2 \mathrm{mg} / 100 \mathrm{ml}$.). Abuse of analgesics.

16 Uncharacteristic dyspepsia and fatigue. The cause of the elevated B.S.R. unknown. Hypercholesterolaemia (serum cholesterol $601 \mathrm{mg} . / 100 \mathrm{ml}$.). Psychiatric examination anxiety neurosis. Abuse of analgesics.

IV 17 From infancy attacks of jaundice, dark urine, and fatigue.

18 From adolescence attacks of jaundice, dark urine, and fatigue.

19 For one year variable, slight jaundice and pruritus.

20 For 7 years frequent attacks of jaundice, abdominal pain, and fatigue.

21 Uncharacteristic abdominal pain, chronic constipation. Climacteric symptoms and fatigue. Peritoneoscopy: normal.

22 Loss of weight (about $20 \mathrm{~kg}$.) since menopause 4 years previously. Psychiatric examination presenile dementia.

23 For several years attacks of severe pain in right hypochondrium. Several laparotomies, some exploratory, without abnormal findings. Fatigue and loss of weight. Psychiatric examination, hysterical neurosis. Peritoneoscopy: normal.

24 Uncharacteristic dyspepsia and fatigue. Numerous diffuse complaints. Psychiatric examination, depressive neurosis.

25 For 3 years uncharacteristic dyspepsia and fatigue. Radiograph after barium meal, small duodenal ulcer. Psychiatric examination, presenile dementia. Peritoneoscopy normal.

26 For about 15 years uncharacteristic abdominal pain. Four years ago nephropexia. Psychiatric examination, psychosomatic neurosis. Abuse of analgesics.

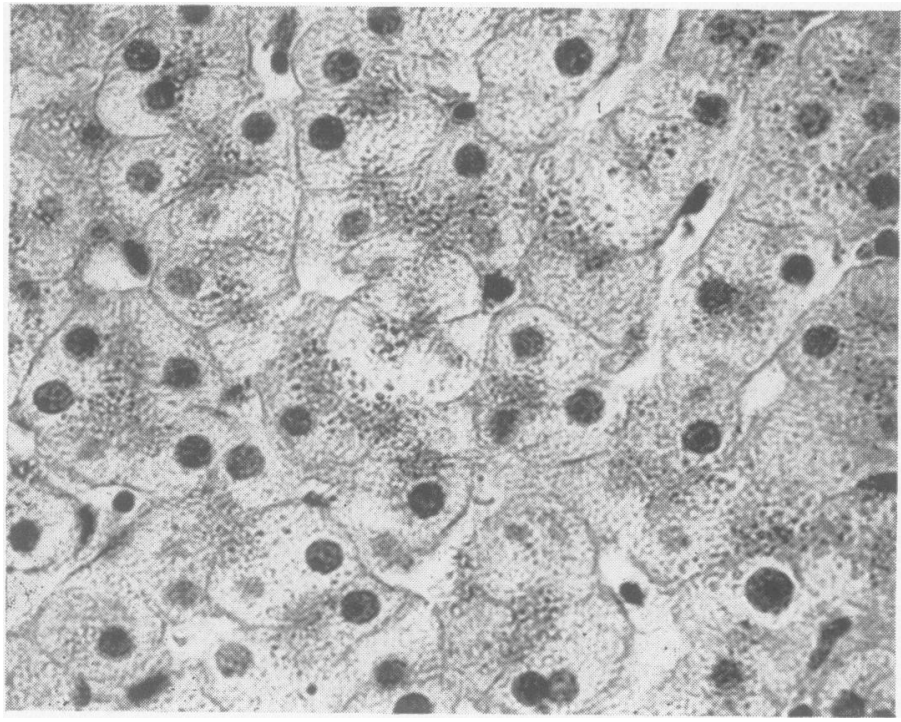

FIG. 1. Needle biopsy from the liver, showing grade +++ deposition of pigment granules in the parenchymal cells (haematoxylin and eosin $\times 920$ ). 


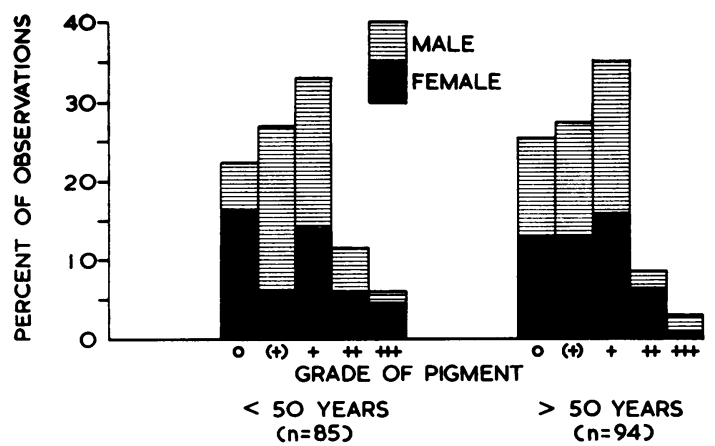

FIG. 2. Relative frequency of grades of pigmentation in relation to age and sex.

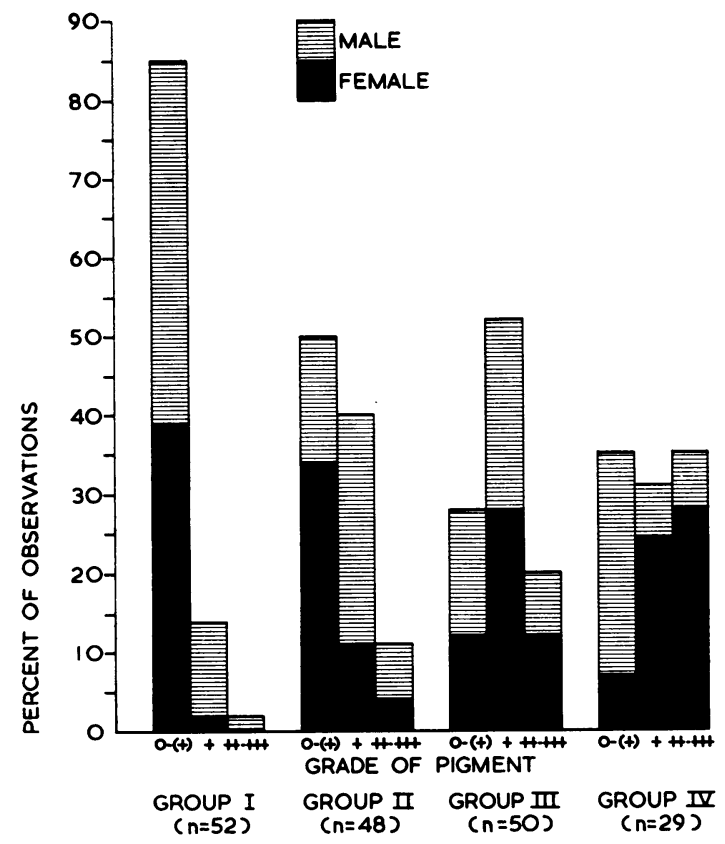

FIG. 3. Relative frequency of grades of pigmentation in relation to clinical diagnosis (group $1=$ cirrhosis of the liver, group $I I=$ other hepatic diseases, group $I I I=$ extrahepatic diseases, group $I V=$ no organic disorders, including patients with constitutional hyperbilirubinaemia).

younger patients and in $12 \%$ of the older ones. This difference was not statistically significant. Nineteen per cent of the women and $11 \%$ of the men belonged to these groups, and the difference between these figures also was insignificant.

Figure 3 shows the frequency of the grades of pigmentation in four clinical groups. Group I consists of patients with cirrhosis of the liver of varying aetiology, group II of patients with other liver diseases (viral hepatitis, cholestatic jaundice, metastases to the liver, chronic hepatic congestion). Group III includes patients with a variety of chronic, more or less debilitating, diseases with possible but unproven hepatic involvement ('wear and tear'). The remaining patients are placed in group IV which consequently consists of patients in whom no sign of significant organic abnormality was demonstrable. In several cases it was disputable whether a patient should belong to group III or to group IV and were all included in group III. Group IV also comprises patients with constitutional hyperbilirubinaemia, since it is generally agreed that this is not a disease strictly speaking.

It appears from Fig. 2 that the relative frequency of patients with marked pigmentation increases steadily through the groups, from 2 to $35 \%$. Clinical data of these patients in groups I and II present no striking similarities, and among the pigmented patients in group III there is no single common feature. It is noteworthy, however, that five patients presented pulmonary infiltrates, in one probably tuberculous (case 11), but in the others of obscure origin (cases $7,8,9$, and 10). Three patients suffered from more or less well-defined 'collagen disease' (cases 6, 7, and 8), and four patients had taken drugs (hypnotics, analgesics) in large amounts (cases 6, 13, 15 , and 16). All patients in group III examined by peritoneoscopy showed marked capsular fibrosis of the liver (cases 7, 8,11, and 14), whereas this was not the case in any of the patients examined from group IV (cases 21, 23, and 25).

In five patients the liver was enlarged (cases 7,8 , 11,12 , and 14). In case 7 this may have been secondary to collagen disease (abnormal liver tests) or an early sign of the congestive heart failure which later became manifest. In that case he should belong to group II. In the remaining four patients there was no evidence of a connexion between the main disease and the hepatomegaly, and in some cases it had been diagnosed many years earlier. Apart from the pigmentation the histology of the liver was normal, as were the liver tests.

In group IV the patients with marked hepatic pigmentation fall into two categories. Cases 17 to 20 gave a history of recurrent jaundice. As no other evidence was found of diseases of the liver and blood, they were regarded as cases of constitutional hyperbilirubinaemia.

Cases 21 to 26 appeared to be a fairly homogenous group. They were all middle-aged, asthenic women, whose complaints were vague, mostly of tiredness and uncharacteristic abdominal pains. They looked worn out, with an ashy complexion, the skin of the face was atrophic and wrinkled, making them look older than their age. The main diagnosis of these 
patients was psychiatric (neurosis, neurasthenia, presenile dementia). In several patients the diagnosis of Addison's disease was considered, but adrenal cortical function proved to be normal. The same features were recognized in four patients from group III (cases 13-16), but in these patients there was also manifest, organic disease.

\section{DISCUSSION}

The high frequency of deposition of lipofuscin granules in the parenchymal liver cells found in this work might lead to the conclusion that the pigmentation is simply a feature of the normal histological picture of the human liver. Unfortunately it is impossible to infer the frequency in the population from the frequency of a biopsy material. The latter is highly selected by the indication for taking a liver biopsy. Furthermore this indication is a highly variable factor, as shown by the great variation in the number of biopsies performed each year. Usually there are many cirrhotic livers in a series of biopsies, and as relatively few of them contain the pigment (Post et al., 1951; Bachmann, 1953) this will reduce the overall frequency. On the other hand, in the present material several of the biopsies with much pigment in groups III and IV were obtained during a search for the phenomenon among patients with hepatomegaly of unknown origin and with constitutional hyperbilirubinaemia, and in asthenic, middle-aged women with the typical 'lipofuscin look'. If the hepatic pigmentation in these patients is not purely accidental, this will result in over-representation of pigment-containing livers in relation to the general population.

There is no reason to doubt, however, that some degree of lipofuscin deposition in the liver is frequently found in subjects who appear to be perfectly healthy. The search for a connexion between pathological processes and the pigmentation therefore in the first place must be restricted to cases with greater than 'normal' deposition of pigment. It is possible that these cases simply represent the upper end of the normal frequency distribution. This question could be solved by analysing sufficiently large comparable groups of patients with and without pronounced pigmentation. The present material, not collected with this purpose, is unsuited in this respect, being too small and heterogenous, but it gives some indications as to the pecularities one might find in the group with heavy pigmentation.

It may be regarded as an established fact that old age and liver disease (or at least cirrhosis) are not connected with accumulation of pigment in the liver. The relation between the pigment and a certain type of constitutional hyperbilirubinaemia, the
Dubin-Johnson syndrome, is well known, but as mentioned the qualitative and quantitative aspects of the relationships are obscure. This foreshadows even greater difficulties in elucidating the relation between the pigmentation and the rather vague clinical conditions found in the present material.

The patients presented with constitutional hyperbilirubinaemia and pigment in the liver are not typical examples of the Dubin-Johnson syndrome, as they all were able to concentrate the cholecystographic contrast medium in the gall bladder, and two of the three patients tested showed normal retention of bromsulphalein. It has been shown, however (Wolf, Pizette, Richman, Dreiling, Jacobs, Fernandez, and Popper, 1960), that in families with typical cases patients may be found who show such minor deviations, and it seems most relevant to include our patients in this group till its limits have been more sharply defined.

So far more objective criteria for definition of the 'lipofuscin look' which we think characterizes 10 of the patients with pigment have not been found. This type of patient, generally presenting difficult diagnostic and therapeutic problems, is probably well known to every doctor. It is uncertain if the psychic or the organic symptoms are primary. It may be speculated that some metabolic disorder may account for the asthenia as well as for the accumulation of lipofuscin in the liver. Similar neurotic complaints have been observed in patients with intermittent hyperbilirubinaemia of the intrahepatic cholestatic type (Summerskill, 1963).

It is also a possibility that the psychic symptoms are primary, and that the accumulation of lipofuscin has been provoked by different treatments given to the patients. It is not known, however, if the pigmentation can be caused by drugs, and not in all patients could a history of intake of larger amounts of drugs be elicited, despite intense interrogation.

The abdominal pains of most of these patients may have a connexion with the lipofuscin in the liver, since similar complaints are frequent in patients with the Dubin-Johnson syndrome (Dubin, 1958). In some of our patients lipofuscin was looked for in biopsies from skin, muscle, lymph nodes, and jejunal mucosa, but nothing abnormal was found.

If a relation between this type of asthenia and lipofuscin in the liver can be substantiated, great efforts should be exerted to find the underlying metabolic lesion, since this may bring a clue to a rational therapy.

The group of patients with pigment and hepatomegaly present different clinical problems. In these patients no other abnormality which could explain the enlargement of the liver could be found, and we think that lipofuscin accumulation should be listed 
among the causes of hepatomegaly. Hepatomegaly as a probable consequence of lipofuscinosis was also observed by Brick and Eckert (1963). This has the practical implication that the finding of lipofuscin in a liver biopsy from a patient with monosymptomatic hepatomegaly should be considered an adequate explanation, making further diagnostic procedures, as, for example, exploratory laparotomy, unnecessary. In other words the attitude of the clinician should be very much the same as if steatosis had been found.

As to the other features found in several patients with lipofuscin accumulation, viz., pulmonary infiltrates, 'collagenosis-like' diseases, large consumption of drugs, and fibrous thickening of the capsule of the liver, their significance cannot be evaluated. There seems to be no $a$ priori reason for their frequent occurrence in such a small series as the present.

No theories regarding the metabolic fate and effects of the lipofuscin can be offered. As studies of the nature of the pigment by histochemical means have not been included, it cannot be stated if the pigments found in the different clinical types are identical in all respects. Identification of the pigment, however, does not depend on highly developed techniques, and with the simple methods used no differences were found.

Our conclusion is that heavy lipofuscin deposition in the liver may be found in several clinical conditions, and at present it is of no value in the clinical diagnosis and management of those diseases. On the other hand there are several indications that it is no trivial phenomenon which should be ignored, and efforts to clarify the causes and effects of lipochrome accumulation in the liver cells should be continued.

\section{SUMMARY}

Re-evaluation of a consecutive series of needle biopsies with regard to the degree of lipofuscin content of the parenchymal cells has shown that marked pigmentation was present in $15 \%$. There was no significant difference in the frequency of heavy pigmentation between patients above and below the age of 50 or between men and women. The frequency was $2 \%$ in patients with cirrhosis, $8 \%$ in patients with other hepatic diseases, $22 \%$ in patients with extrahepatic diseases, and $34 \%$ in patients without a manifest organic disease (including patients with constitutional hyperbilirubinaemia). Clinical features common to all patients with heavy pigmentation were not found, but two types of patient were noted in whom a relationship between the pigmentation and the clinical findings was suspected. One type, represented by four cases, was patients with hepatomegaly in whom no other cause for this abnormality could be found. The other type, represented by 10 cases, was of middle-aged, asthenic women, looking worn out and older than their age, with vague, mostly abdominal, complaints. In six of them the main diagnosis was psychiatric. The possibility that a common metabolic lesion accounts for both the asthenia and the accumulation of lipofuscin in the liver is discussed.

\section{REFERENCES}

Bachmann, K. D. (1953). Über das Lipofuscin der Leber. Virchows Arch. path. Anat., 323, 133-142.

Brick, I. B., and Eckert, G. E. (1963). Lipochrome hepatosis without jaundice (abstract). Gastroenterology, 44, 482.

Burka, E. R., Brick, I. B., and Wolfe, H. R. (1961). 'Lipochrome' hepatosis without jaundice: a variant of the Dubin-Johnson syndrome. Amer. J. med. Sci., 242, 746-749.

Dubin, I. N. (1958). Chronic idiopathic jaundice: a review of 50 cases. Amer. J. Med., 24, 268-292.

— and Johnson, F. B. (1954). Chronic idiopathic jaundice with unidentified pigment in liver cells: a new clinico pathologic entity with a report of 12 cases. Medicine (Baltimore), 33, 155-197.

Ehrlich, J. C., Novikoff, A. B., Platt, R., and Essner, E. (1960). Hepatocellular lipofuscin and the pigment of chronic idiopathic jaundice. Bull. N.Y. Acad. Med., 36, 488-491.

Essner, E., and Novikoff, A. B. (1960). Human hepatocellular pigments and lysomes. J. Ultrastruct. Res., 3, 374-391.

Hamperl, H. (1957). Chronischer nichthämolytischer Ikterus mit Ablagerung eines eigentümlichen Pigmentes in der Leber. Klin. Wschr., 35, 177-179.

Hanser, R. (1930). Lipofuscin. In Handbuch der speziellen pathologischen Anatomie und Histologie, edited by F. Henke and $\mathrm{O}$. Lubersch, vol. V, part I, pp. 191-192. Springer, Berlin.

Pearse, A. G. E. (1960). Histochemistry, Theoretical and Applied, 2nd ed., Churchill, London.

Porush, J. G., Delman, A. J., and Feuer, M. M. (1962). Chronic idiopathic jaundice with normal liver histology. Arch. intern. Med., 109, 302-309.

Post, J., Benton, J. G., and Breakstone, R. (1951). Observations on a cytoplasmic hepatic-cell pigment in man. Arch. Path., 52, 67-72.

Sagild, U., Dalgaard, O. Z., and Tygstrup, N. (1962). Constitutional hyperbilirubinemia with unconjugated bilirubin in the serum and lipochrome-like pigment granules in the liver. Ann. intern. Med., 56, 308-314.

Sprinz, H., and Nelson, R. S. (1954). Persistent nonhemolytic hyperbilirubinemia associated with lipochrome-like pigment in the liver cells: report of 4 cases. Ibid., 41, 952-962.

Summerskill, W. H. J. (1963). Personal communication.

Wolf, R. L., Pizette, M., Richman, A., Dreiling, D. A., Jacobs, W., Fernandez, O., and Popper, H. (1960). Chronic idiopathic jaundice: a study of two afflicted families. Amer. J. Med., 28, 32-41. 